\title{
RAG2 wt Allele
}

National Cancer Institute

\section{Source}

National Cancer Institute. RAG2 wt Allele. NCI Thesaurus. Code C80071.

Human RAG2 wild-type allele is located in the vicinity of $11 \mathrm{p} 13$ and is approximately $6 \mathrm{~kb}$ in length. This allele, which encodes $V(D)$ J recombination-activating protein 2 , is involved in the regulation of immunog lobulin recombination. Mutation of the gene is associated with several hereditary immunodeficiencies. Genetic variation may be associated with the relapse of acute lymphoblastic leukemia. 